\title{
Incorporation of Functionalized Calcium Phosphate Nanoparticles in Living Cells
}

\author{
Manuel Rivas ${ }^{1}\left(\mathbb{D} \cdot\right.$ Pau Turon $^{2} \cdot$ Carlos Alemán $^{1} \cdot$ Jordi Puiggalí $^{1} \cdot$ Luis J. del Valle $^{1}$
}

Received: 14 July 2021 / Accepted: 17 September 2021 / Published online: 5 November 2021

(C) The Author(s) 2021

\begin{abstract}
Intracellular calcium $\left(\mathrm{Ca}^{2+}\right)$ is a key signaling element that is involved in a great variety of fundamental biological processes. Thus, $\mathrm{Ca}^{2+}$ deregulation would be involved in the cancer cell progression and damage of mitochondrial membrane and DNA, which lead to apoptosis and necrosis. In this study, we have prepared amorphous calcium phosphate nanoparticles (ACP NPs) for studied their incorporation by endocytosis or electroporation to epithelial, endothelial and fibroblast cells (MCF-7, HUVEC and COS-1 cells, respectively). Our results showed that internalized ACP NPs have cytotoxic effects as a consequence of the increase of the intracellular calcium content. The endocytosis pathways showed a greater cytotoxic effect since calcium ions could easily be released from the nanoparticles and be accumulated in the lysosomes and mitochondria. In addition, the cytotoxic effect could be reversed when calcium ion was chelated with ethylene glycol-bis(2-aminoethylether)-N, $\mathrm{N}^{\prime} \mathrm{N}^{\prime}, \mathrm{N}^{\prime}$-tetraacetic acid (EGTA). Modification of ACP NPs by coating with different compounds based on phosphates was also evaluated. The results indicated a reduction of the cytotoxic effect, in the order polyphosphate $<$ phosphonic acid $<$ orthophosphate. A differential cytotoxic effect of ACP-NPs was observed in function of the cell type; the cytotoxic effect can be ordered as i.e., HUVEC $>$ COS-1 > MCF-7. The greater cytotoxic effect caused by the increase of intracellular calcium that is observed in normal cells and the greater resistance of cancer cells suggests new perspectives for cancer research.
\end{abstract}

Keywords Amorphous calcium phosphate - Nanoparticles · Cytotoxic effect · Cancer · Intracellular calcium

\section{Introduction}

Calcium $\left(\mathrm{Ca}^{2+}\right)$ is a key signaling element that is involved in a great variety of fundamental biological processes (e.g. from fertilization to programmed cell death). Thus, almost every tissue and biofluid has specific functions that are controlled by $\mathrm{Ca}^{2+}[1]$. Besides, calcium is the most abundant metallic element in the body, being adequate intake amounts (1.0-1.2 g/day) obtained from dairy

Jordi Puiggalí

jordi.puiggali@upc.edu

$\square$ Luis J. del Valle

luis.javier.del.valle@upc.edu

1 Departament d'Enginyeria Química and Barcelona Research Center for Multiscale Science and Engineering EEBE, Universitat Politècnica de Catalunya, Av. Eduard Maristany 16, 08019 Barcelona, Spain

2 B. Braun Surgical, S.A., Carretera de Terrassa 121, 08191 Rubí, Barcelona, Spain products and some green vegetables. However, calcium has recently been associated with some risk of cancer. For example, colorectal cancer [2-4], accumulation of calcium in the peripheral zone of human prostate gland could play an important role in the prostate cancer [5].

Calcium deregulation has extensively been studied at cellular and molecular levels due to its clear effect on cell injury, carcinogenesis and cell death [6, 7]. For instance, $\mathrm{Ca}^{2+}$ can activate transcription factors, such as nuclear factor of activated T cells (NFAT) [6], regulate cell proliferation promoting cancer cell progression [8], modulate poly-ADP-ribose polymerase, permeabilization of mitochondrial membrane and DNA damage leading to apoptosis and necrosis [9].

Calcium is also a key regulator of the mitochondrial function and acts at several levels within the organelle to stimulate ATP synthesis. Deregulation of mitochondrial $\left[\mathrm{Ca}^{2+}\right]$ homeostasis is now recognized to play a key role in several pathologies (e.g. enhanced generation of reactive oxygen species (ROS), release of cytochrome C, and 
alteration of the activity of the mitochondrial permeability transition pore) [10], which can lead again to apoptosis and necrosis [11].

It has recently been suggested that cancer cells may have a mitochondrial dysfunction, being adapted to aerobic glycolysis in order to generate ATP. The signaling role of ROS has been recognized [12]. Recent studies suggest that cancer cells, compared with normal cells, undergo an increased oxidative stress that can be associated with oncogenic transformation, alterations in metabolic activity, and increased generation of ROS [13]. In turn, the increased ROS in cancer cells may affect certain redoxsensitive molecules and further lead to significant consequences, such as stimulation of cellular proliferation, cell differentiation, alterations in sensitivity to anticancer agents, promotion of mutations and genetic instability, and contribution to carcinogenesis [13]. Perturbation of mitochondrial respiration in cancer cells leads to redox alterations and highly invasive behaviors, which seem to be mediated by elevated cytosolic calcium [14].

Until recently, necrosis, unlike apoptosis, was considered as passive and unregulated form of cell death. However, during the last decade a number of experimental data demonstrated that, except under extreme conditions, necrosis may be a well-regulated process activated by rather specific physiological and pathological stimuli [15]. Proskuryakov et al. have considered mechanisms and the role of necrosis in tumor cells [16]. Mitochondrial collapse activates various proteases (e.g. calpains and cathepsin) and phospholipases, and eventually leads to plasma membrane destruction, a hallmark of necrotic cell death. Necrosis, in contrast to apoptosis, usually evokes powerful inflammatory response, which may participate in tumor regression during anticancer therapy. However, excessive spontaneous necrosis during tumor development may lead to more aggressive tumors due to the stimulated growth caused by the necrosis-induced inflammation [16].

In this study, we have addressed on the particular histological architecture of tumors. Willis defined a tumor (neoplasm) as a mass, the growth of which is uncoordinated with the surrounding normal tissues and persists in the absence of the inciting stimulus [17]. It is worth considering this definition in detail. First, the mass, like any other tissue, is composed of parenchymal cells and stroma, which are the essential parts of an organ. The parenchymal cells of the mass may be well differentiated, organized as normal tissues, and had a slow proliferation, or on the contrary, they may be poorly differentiated, had little or no organization and a fast proliferation. In either situation, the host response is mediated by angiogenic factors [18, 19], which are synthesized by the parenchyma of the tumor and stimulate proliferation of all stromal cells, including fibroblasts and vascular cells.

Hydroxyapatite (HAp) nanoparticles are able to encapsulate different drugs (e.g. chloramphenicol) [20] and also to be internalized by endocytosis due to their small size. These nanoparticles are also a source of $\mathrm{Ca}^{2+}$ ions, which can be delivered inside cells due to their solubilization in acidic media. The released $\mathrm{Ca}^{2+}$ can be accumulated in lysosomes and mitochondria provoking a necrotic effect, which deserves also the attention of the present work. In this work, we explore the intracellular incorporation pathway of $\mathrm{Ca}^{2+}$ free and released from the calcium phosphate nanoparticles (NPs), the influence of the size being also investigated in the latter case (i.e. NPs $<200 \mathrm{~nm}$ and NPs $>200 \mathrm{~nm}$ ).

\section{Materials and Methods}

\section{Materials}

Tetrasodium pyrophosphate $\left(\mathrm{Na}_{4} \mathrm{P}_{2} \mathrm{O}_{7}\right)$, sodium triphosphate (polyP), aminotris(methylenephosphonic acid) (ATMP), ammonium phosphate dibasic $\left[\left(\mathrm{NH}_{4}\right)_{2} \mathrm{HPO}_{4}\right.$; purity $\geq 99.0 \%$ ] and ammonium hydroxide solution $30 \%$ ( $\mathrm{NH}_{4} \mathrm{OH}$; purity: 28-30\%) were purchased from SigmaAldrich. Calcium nitrate $\left[\mathrm{Ca}\left(\mathrm{NO}_{3}\right)_{2}\right.$; purity $\left.\geq 99.0 \%\right]$ was purchased from Panreac (Barcelona, Spain). Ethanol $\left(\mathrm{C}_{2} \mathrm{H}_{5} \mathrm{OH}\right.$; purity $\left.\geq 99.5 \%\right)$ was obtained from Scharlab (Barcelona, Spain). HEPES was purchased from Lonza.

Cell line MCF-7 (epithelial cells from human breast adenocarcinoma) and COS-1 (fibroblast cells from green monkey kidney transformed by insertion of the SV40) were obtained from ATCC (HTB-22 and CRL-1650, respectively). Dulbeccós Modified Eaglés Medium (DMEM) and $\mathrm{Ca}^{2+}$-free DMEM, Fetal Bovine Serum (FBS), penicillin/ streptomycin (pen/strep) and L-glutamine were purchased from Gibco. Cell line HUVEC (endothelial cells from normal human umbilical vein) (CC-2517) and EGM-2 Bulletkit with and without $\mathrm{Ca}^{2+}$ media optimized for certain HUVECs were purchased from Lonza. Poly-L-lysine was purchased from Merck Millipore (Germany).

Fura-2AM, Alamar blue reagent and ethylene glycolbis(2-aminoethylether)-N,N, $\mathrm{N}^{\prime}, \mathrm{N}^{\prime}$-tetra(acetoxymethyl ester) (EGTA-AM) were purchase from Invitrogen (Invitrogen-Molecular Probes, Leiden, The Netherlands). MTT solution [3-(4,5-dimethylthiazol-2-yl)-2,5-diphenyltetrazolium bromide] was purchased from Roche. Texas red dextran (MW 10,000 g/mol); and both enzymes, trypsinEDTA solution (0.05\% trypsin, $0.02 \%$ EDTA) and soluble alkaline phosphatase (10 units/mL) from bovine intestinal 
mucosa were purchased from Sigma-Aldrich. Electroporation cuvettes were purchased from Molecular BioProducts Inc.

\section{Synthesis of Amorphous Calcium Phosphate (ACP)}

Amorphous calcium phosphate nanoparticles (ACP-NPs) have been considered for this study. The reagent conditions were adjusted to get a $\mathrm{Ca} / \mathrm{P}$ ratio of 1.67 . Specifically, $15 \mathrm{~mL}$ of $0.5 \mathrm{M}\left(\mathrm{NH}_{4}\right)_{2} \mathrm{HPO}_{4}$ in milli-Q water $(\mathrm{pH} 11$ adjusted with ammonium hydroxide $30 \% \mathrm{w} / \mathrm{v}$ solution) were drop-wise added (rate of $2 \mathrm{~mL} / \mathrm{min}$ or less) under agitation (400 rpm) to $25 \mathrm{~mL}$ of a $0.5 \mathrm{M} \mathrm{Ca}\left(\mathrm{NO}_{3}\right)_{2}$ ethanol solution. The reaction mixture was stirred during $1 \mathrm{~h}$ (400 rpm at room temperature). The reagents and the reaction were made in plastic containers to avoid the use of borosilicate glasses. Then, the resultant suspension of NPs was aged for $24 \mathrm{~h}$ at $37{ }^{\circ} \mathrm{C}$. The precipitate was separated by centrifugation and washed sequentially with milli-Q water and a 60/40 v/v mixture of ethanol-water (twice). A white powder was obtained after freeze-drying.

\section{Size Separation of NPs}

The ACP-NPs were re-suspended in milli-Q water at concentration of $15 \mathrm{mg} / \mathrm{mL}$. The procedure was performed according to BS ISO 14887 (2000) ("Sample preparationdispersing procedures for powders in liquids"). Thus, NPs powder $(300 \mathrm{mg})$ was placed in a plastic tube of $50 \mathrm{~mL}$ together with $10 \mathrm{~mL}$ of water sterile and mixed with a spatula until all visible aggregates disappeared. The wetting step was applied in order to substitute the solid-air interface by a solid-liquid interface. $10 \mathrm{~mL}$ of water were then added to the tube and gently mixed using a spatula. The tube was subsequently immersed in an ice bath and the sample was sonicated to ensure a complete de-agglomeration using an ultrasonic probe (Cole-Parmer ${ }^{\circledR}$ 130-Watt Ultrasonic Processors (50/60 Hz, VAC 220); product number EW-04714-51). A titanium probe of $6 \mathrm{~mm}$ was tuned to resonate at $20 \mathrm{kHz}, \pm 50 \mathrm{~Hz}$ for $20 \mathrm{~s}$ at $90 \%$ amplitude.

The NPs suspension was then gently mixed with a spatula rod to ensure homogeneity, and loaded in a syringe $(10 \mathrm{~mL})$ to be filtered through a $0.2 \mu \mathrm{m}$ filter. Filtration was manually performed at a flow rate approximately of $1 \mathrm{~mL} / \mathrm{min}$, particles were finally concentrated using an IEC MultiRF centrifugue (Thermo IEC, Needham Heights, MA, USA). Two fractions corresponding to the eluted (i.e. NPs size $<200 \mathrm{~nm}$ ) and retained particles (i.e. NPs with size $>200 \mathrm{~nm}$ ) were consequently obtained.

\section{Measurements}

\section{X-ray Diffraction}

Crystallinity was studied by wide angle X-ray diffraction (WAXD). Patterns were acquired using a Bruker D8 Advance model with $\mathrm{CuK}_{\alpha}$ radiation $(\lambda=0.1542 \mathrm{~nm})$ and geometry of Bragg-Bretano, theta- 2 theta. A one-dimensional Lynx Eye detector was employed. Samples were run at $40 \mathrm{kV}$ and $40 \mathrm{~mA}$, with a 2-theta range of 2-40, measurement steps of $0.02^{\circ}$, and time/step of 2-8 s. Diffraction profiles were processed using PeakFit v4 software (Jandel Scientific Software) and the graphical representation performed with OriginPro v8 software (OriginLab Corporation, USA).

The crystallite size (L) in the direction perpendicular to the representative (211) planes of samples was derived from the X-ray diffraction line broadening measurement using the Scherrer equation: [21]

$L=\frac{0.9 \lambda}{\beta \cos \theta}$

where $\lambda$ is the wavelength $\left(\mathrm{CuK}_{\alpha}\right), \beta$ is the full width at half maximum height of the (211) line, $\theta$ is the diffraction angle and 0.9 is a shape factor. The crystallinity $\left(\chi_{c}\right)$ was obtained using the following equation [22]:

$\chi_{c}=1-\frac{\mathrm{V}_{112 / 300}}{\mathrm{I}_{300}}$

where $I_{300}$ is the intensity of the (300) reflection and $\mathrm{V}_{112 / 300}$ is the intensity of the hollow between the (112) and (300) reflections, which disappears in non-crystalline samples.

\section{Morphological Characterization}

Scanning electron microscopy (SEM) studies were carried out using a Focused Ion Beam Zeiss Neon40 microscope operating at $5 \mathrm{kV}$, equipped with an energy dispersive X-ray (EDX) spectroscopy system. Samples were deposited on a silicon disc mounted with silver paint on pin stubs of aluminum, and sputter-coated with a thin layer of carbon to prevent sample charging problems.

\section{Adsorption of Biophosphates and Biophosphonate Onto ACP NPs $<200 \mathrm{~nm}$}

ACP nanoparticles were prepared and filtered using the above described procedure. After this, $500 \mu \mathrm{L}$ of working aqueous solution ( $\mathrm{pH} 7.4$, adjusted with an ammonium hydroxide $30 \%-\mathrm{w} / \mathrm{w}$ solution), which contained $12.5 \mathrm{mM}$ of polyP, $\left(\mathrm{P}_{2} \mathrm{O}_{7}\right)^{4-}$ or ATMP, were deposited onto $50 \mathrm{mg}$ of ACP NPs $<200 \mathrm{~nm}$. After overnight agitation at $25^{\circ} \mathrm{C}$, 
adducts were separated by centrifugation at $6500 \mathrm{rpm}$ and $4{ }^{\circ} \mathrm{C}$ during $4 \mathrm{~min}$. Sediments were washed with milli-Q water for two-times. The obtained pellets were frozen at $80^{\circ} \mathrm{C}$ for $3 \mathrm{~h}$ and lyophilized to remove the humidity. These ACP NPs were named according to their coating as NPs/polyP, NPs/ $/\left(\mathrm{P}_{2} \mathrm{O}_{7}\right)^{4-}$ and NPs/ATMP. The ability of ACP to adsorb polyP, $\mathrm{P}_{2} \mathrm{O}_{7}^{4-}$ and ATMP was determined using FTIR spectroscopy.

Some experiments were performed with nanoparticles treated with alkaline phosphatase to remove the added coating. This treatment is specific to hydrolyze the biophosphates in the NPs/polyP and NPs/ $\left(\mathrm{P}_{2} \mathrm{O}_{7}\right)^{4-}$ samples [23]. The uncoated NPs and NPs/ATMP were used as controls. The hydrolysis medium consisted of 10 units $/ \mathrm{mL}$ of soluble alkaline phosphatase in $100 \mathrm{mM}$ Tris- $\mathrm{HCl}$ buffer and $200 \mathrm{mM} \mathrm{MgCl} 2$ at $\mathrm{pH}$ 7.4. The uncoated and coated NPs were incubated in this medium overnight at 37 ${ }^{\circ} \mathrm{C}$ under orbital agitation. Then, adducts were separated by centrifugation at $6500 \mathrm{rpm}$ during $5 \mathrm{~min}$. Sediments were washed with milli-Q water for two-times. Pellets were frozen at $-80{ }^{\circ} \mathrm{C}$ for $3 \mathrm{~h}$ and lyophilized to remove the humidity. Finally, these NPs were used in electroporation $(+\mathrm{EP})$ and non-electroporation (-EP) experiments as above described.

\section{Fourier Transform Infrared (FTIR) Spectroscopy}

Infrared absorption spectra were recorded with a Fourier Transform FTIR 4100 Jasco spectrometer in the 1800-700 $\mathrm{cm}^{-1}$ range. A Specac model MKII Golden Gate attenuated total reflection (ATR) equipment with a heated Diamond ATR Top-Plate was used. The characteristic bands of the compounds studied in this work (substrates and adsorbed species) are listed in Table 1 .
X-ray Photoelectron Spectroscopy (XPS)

XPS analyses were performed in a SPECS system equipped with a high-intensity twin-anode X-ray source XR50 of $\mathrm{Mg} / \mathrm{Al}(1253 \mathrm{eV} / 1487 \mathrm{eV})$ operating at $150 \mathrm{~W}$, placed perpendicular to the analyzer axis, and using a Phoibos 150 MCD-9 XP detector. The X-ray spot size was $650 \mu \mathrm{m}$. The pass energy was set to 25 and $0.1 \mathrm{eV}$ for the survey and the narrow scans, respectively. Charge compensation was achieved with a combination of electron and argon ion flood guns. The energy and emission current of the electrons were $4 \mathrm{eV}$ and $0.35 \mathrm{~mA}$, respectively. For the argon gun, the energy and the emission current were $0 \mathrm{eV}$ and $0.1 \mathrm{~mA}$, respectively. The spectra were recorded with a pass energy of $25 \mathrm{eV}$ in $0.1 \mathrm{eV}$ steps at a pressure below $6 \times 10^{-9}$ mbar. These standard conditions of charge compensation resulted in a negative but perfectly uniform static charge. The $\mathrm{C} 1 \mathrm{~s}$ peak was used as an internal reference with a binding energy of $284.8 \mathrm{eV}$. High-resolution XPS spectra were acquired by Gaussian-Lorentzian curve fitting after s-shape background subtraction. The surface composition was determined using the manufacturer's sensitivity factors.

\section{Cell Cultures}

MCF-7 and COS-1 cells were cultured in Dulbeccós Modified Eaglés medium (DMEM) supplemented with $10 \%$ fetal bovine serum (FBS), $1 \%$ pen/strep and $2 \mathrm{mM} \mathrm{L-}$ glutamine. HUVEC cells were cultured in EGM-2 Bulletkit medium. The cells were cultured in $25 \mathrm{~T}$-flask at $37{ }^{\circ} \mathrm{C}$ with $5 \% \mathrm{CO}_{2}, 95 \%$ air and humid atmosphere. The cells of the culture that reached close to $90 \%$ confluence were detached using $0.05 \%$ trypsin/EDTA. Finally, cells were washed and re-suspended in a $\mathrm{Ca}^{2+}$-free culture medium to be counted and treated according to the procedures
Table 1 Characteristic FTIR bands of the species studied in this work

\begin{tabular}{lll}
\hline Compound & & $v$ \\
\hline ACP and cHAp & $\mathrm{PO}_{4}^{3-} v_{1}$ & 962 \\
& $\mathrm{PO}_{4}^{3-} v_{3}$ & $1022,1059,1089$ \\
polyP & $\mathrm{P}-\mathrm{O}-\mathrm{P}$ symmetric stretching & 734 \\
& $\mathrm{P}-\mathrm{O}-\mathrm{P}$ asymmetric stretching & 890 \\
& $\mathrm{PO}_{3}^{2-}$ vibrations & $1100-1200$ \\
& $\mathrm{P}-\mathrm{O}-\mathrm{P}$ symmetric stretching & 736 \\
$\mathrm{P}_{2} \mathrm{O}_{7}^{4-}$ & $\mathrm{P}-\mathrm{O}-\mathrm{P}$ asymmetric stretching & 889 \\
& $\mathrm{PO}_{3}^{2-}$ vibrations & $1100-1200$ \\
& $\mathrm{P}-\mathrm{O}-\mathrm{CH}$ stretching & 1070 \\
$\mathrm{ATMP}$ & Asymmetric vibrations of alkylphosphonic & 939 \\
& Symmetric vibrations of alkylphosphonic & 1000 \\
& $\mathrm{P}-\mathrm{C}$ stretching & 985 \\
\hline
\end{tabular}


described below. The growth of the cells (i.e. during $48 \mathrm{~h}$ ) in these $\mathrm{Ca}^{2+}$-free media was performed as a control, being cell viability always greater than $95 \%$.

\section{Microinjection of $\mathrm{Ca}^{2+}$ and NPs Into Cells}

MCF-7 and COS-1 cells were seeded onto glass cover slides of $0.8 \mathrm{~cm}$ diameter, which had previously been coated with $0.01 \%$ poly-L-lysine. Coating was performed overnight at $37{ }^{\circ} \mathrm{C}$ and under agitation. Cover slides were subsequently washed twice with PBS and absolute ethanol for sterilization. Finally, they were left in a laminar flow cabinet until the ethanol in excess was evaporated.

$1.5 \times 10^{3}$ cells were seeded onto each cover slide and cultured during $24 \mathrm{~h}$ before being microinjected. This procedure allow that attached cells to resist the tensile stress that occur during the microinjection process. This was performed according to previously described procedures [24, 25]. Glass capillary (outer diameter of $2 \mathrm{~mm}$ ) micropipettes (W-P Instruments, New Haven, CT) were prepared using a micropipette puller (PG-1, Narishige Scientific Instruments, Tokyo, Japan) that allowed getting a diameter of the tip close to $0.5-1.0 \mu \mathrm{m}$. After the capillary was pulled, the solution was delivered through its rear open end by means of a microloader (Eppendorf Microloader). The micropipette was then connected to the hub of the pipette holder, which was attached to the microinjector. Operations were done using a micromanipulator (Eppendorf 5171) and a microinjector (Eppendorf 5246) coupled with an inverted microscope (Olympus, Hamburg, Germany), which was equipped with phase-contrast and fluorescence optics. The temperature was maintained at $37{ }^{\circ} \mathrm{C}$ by using a plastic housing with an incubator (i.e. having supply of hot air and $\mathrm{CO}_{2}$ ).

Microinjection was controlled using a tracer based on a loading buffer $\left(4.8 \mathrm{mM} \mathrm{K} \mathrm{K}_{2} \mathrm{HPO}_{4}, 4.5 \mathrm{mM} \quad \mathrm{KH}_{2} \mathrm{PO}_{4}\right.$, $14 \mathrm{mM} \mathrm{NaH}_{2} \mathrm{PO}_{4}$ at $\mathrm{pH} 7.4$ ), solution of $\mathrm{CaCl}_{2}$ and Texas red dextran (final concentration, $10 \mathrm{mg} / \mathrm{mL}$ ) with $M_{W}$ of $10,000 \mathrm{~g} / \mathrm{mol}$. The selected conjugate can remain in the microinjection place, while lower molecular weight conjugates (e.g. $3000 \mathrm{~g} / \mathrm{mol}$ ) can move from cytoplasm to the nucleus and vice-versa.

The tracer fluorescence $(410-485 \mathrm{~nm} / 515 \mathrm{~nm}, \mathrm{Ex} / \mathrm{Em})$ was followed by taking images (1-10 min after microinjection). Suspensions of both kinds of NPs (i.e. $<200 \mathrm{~nm}$ and $>200 \mathrm{~nm}$ ) were prepared using the same loading buffer.

\section{$\mathrm{Ca}^{2+}$ Imaging Using Fura-2}

$\mathrm{Ca}^{2+}$-free, NPs $<200 \mathrm{~nm}$ and NPs $>200 \mathrm{~nm}$ were microinjected to obtain an intracellular $\mathrm{Ca}^{2+}$ concentration of $400 \mathrm{nM}$. The time-course of this $\mathrm{Ca}^{2+}$ was followed with Fura-2 indicator. Specifically, the pipette was filled with $10 \mu \mathrm{L}$ of the injection fluid having $1 \mathrm{mM}$ Fura-2AM. Intracellular, unspecific esterases transform the acetoxymethyl ester (AM) to formaldehyde and acetic acid, which leads to the liberation of the $\mathrm{Ca}^{+2}$ indicator (i.e. Fura-2). The measurements of Fura-2 were carried out in an Olympus $\mathrm{I} \times 81$ motorized inverted microscope (Olympus, Hamburg, Germany) controlled by Cell^ $\mathrm{M}$ software (Olympus Soft Imaging Solution). Fura-2 was alternately excited at 340 and $380 \mathrm{~nm}$ every $3 \mathrm{~min}$ and the emitted fluorescence was detected at $>500 \mathrm{~nm}$. The changes of Fura-2 fluorescence were analyzed with the Cell^ $\mathrm{M}$ software.

\section{Analysis of Surface Blebs}

Microinjections were performed as described above. $\mathrm{Ca}^{2+}$ free, NPs $<200 \mathrm{~nm}$ and NPs $>200 \mathrm{~nm}$ were microinjected to obtain intracellular $\mathrm{Ca}^{2+}$ concentrations of: 0 , $100,200,400$ and $800 \mathrm{nM}$. After $24 \mathrm{~h}$ of culture, images of the injected cells were taken by phase contrast microscopy and the percentage of the blebs surface was calculated on the basis of the total surface of the cells. Blebbing of the plasma membrane is a typical feature of cells undergoing late stage of apoptosis and is usually evaluated through the visible increase of the cytoplasmic diameter. Calculations were carried out by taking micrographs after microinjection at intervals of 1 min during $24 \mathrm{~h}$ and then during an additional period of $90 \mathrm{~min}$ to determine its stability. Time-lapse and images were analyzed using the EVOSTM software.

\section{Electroporation of $\mathrm{Ca}^{2+}$ and NPs Into Cells}

Electroporation was carried out using a BTX T820 square wave electroporator (BTX Harvard Apparatus). The electroporation parameters for each cell line were optimized for high electro-permeabilization and low cellular death. The cells were suspended in a $\mathrm{pH} 7$ HEPES buffer $(10 \mathrm{mM}$ HEPES, $250 \mathrm{mM}$ sucrose and $1 \mathrm{mM} \mathrm{MgCl}_{2}$ in sterile water) at concentration of $6.1 \times 10^{6}$ cells $/ \mathrm{mL}$. Then, 270 $\mu \mathrm{L}$ of cell suspension (cooled at $\sim 8{ }^{\circ} \mathrm{C}$ ) were electroporated in presence of different concentrations of supplemented $\mathrm{Ca}^{2+}$ (i.e. 0, 0.025, 0.05, 0.1, 0.2, 0.4, 0.6, 0.8, 1.6 and $3.2 \mathrm{mM}$ ). Electroporations were carried out in cuvettes of $4 \mathrm{~mm}$ and using 8 pulses of $99 \mu$ s with $1.4 \mathrm{kV} / \mathrm{cm}$ and $1 \mathrm{~Hz}$ for MCF-7 cells, $1.2 \mathrm{kV} / \mathrm{cm}$ and $1 \mathrm{~Hz}$ for COS- 1 cells, and $1.0 \mathrm{kV} / \mathrm{cm}$ and $1 \mathrm{~Hz}$ for HUVEC cells. These conditions depend on the cell type. The same procedure was performed for NPs $<200 \mathrm{~nm}$ and NPs $>200 \mathrm{~nm}$. After electroporation, cells were washed two-times and resuspended in a $\mathrm{Ca}^{2+}$-free medium. Then, cells were incubated at $37{ }^{\circ} \mathrm{C}$ and $5 \% \mathrm{CO}_{2}$ during $20 \mathrm{~min}$. The protocol 
was slightly changed when $\mathrm{Ca}^{2+}$ and NPs were chelated with EGTA. In these cases, cells were twice washed after electroporation and re-suspended in a $\mathrm{Ca}^{2+}$-free medium supplemented with $0.5 \mathrm{mM}$ EGTA-AM. Finally, they were washed in culture medium and diluted to be seeded in 96-well plates at a density of $10^{4}$ cells $/ 200 \mu \mathrm{L}$ in each well. Assays were performed in triplicate at $24 \mathrm{~h}$ and $48 \mathrm{~h}$ of culture, the MTT and Alamar blue assays were selected to determine cell viability.

\section{Loading of $\mathrm{Ca}^{2+}$ and ACP NPs Into Cells Without Electroporation}

The cells after trypsinization were seeded in 96-well plates at a density of $10^{4}$ cells $/ 100 \mu \mathrm{L}$ in each well. For this, a $\mathrm{Ca}^{2+}$-free culture medium was used, and the plates were maintained under culture conditions for $24 \mathrm{~h}$ to allow cell adhesion. Then, $100 \mu \mathrm{L}$ of the medium with $2 \mathrm{X}$ concentrations of $\mathrm{Ca}^{2+}$ were added to each well, to achieve the appropriate concentrations of $\mathrm{Ca}^{2+}$ (i.e. 0, 0.025, 0.05, 0.1, $0.2,0.4,0.6,0.8,1.6$ and $3.2 \mathrm{mM})$. The same procedure was performed for NPs $<200 \mathrm{~nm}$ and NPs $>200 \mathrm{~nm}$ to obtain equivalent concentrations of $\mathrm{Ca}^{2+}$ despite being contained in the NPs. Each condition was tested in triplicate. At $24 \mathrm{~h}$ and $48 \mathrm{~h}$ of culture, the MTT and Alamar Blue assays were performed to determine cell viability using the $\mathrm{CC}_{50}$ value. The $50 \%$ cytotoxic concentration $\left(\mathrm{CC}_{50}\right)$ was defined as the $\mathrm{Ca}^{2+}$ concentration that reduced the cell viability by $50 \%$ when compared to untreated controls.

For the cases of $\mathrm{Ca}^{2+}$ and NPs chelated with EGTA, the cells after trypsinization were electroporated in the HEPES buffer supplemented with $0.5 \mathrm{mM}$ EGTA-AM in the above described conditions. Subsequently, cells were incubated at $37{ }^{\circ} \mathrm{C}$ and $5 \% \mathrm{CO}_{2}$ during $20 \mathrm{~min}$. Then, they were washed and diluted in a $\mathrm{Ca}^{2+}$-free culture medium supplemented with $0.5 \mathrm{mM}$ EGTA-AM to be seeded in 96-well plates at a density of $10^{4}$ cells $/ 100 \mu \mathrm{L}$ in each well. After $24 \mathrm{~h}$ of culture, the medium was changed with $200 \mu \mathrm{L}$ of fresh medium supplemented with 0.5 mM EGTA-AM and $\mathrm{Ca}^{2+}$ free in different concentrations (i.e. 0, 0.025, 0.05, 0.1, 0.2, $0.4,0.6,0.8,1.6$ and $3.2 \mathrm{mM}$ ). The similar procedure was performed for NPs $<200 \mathrm{~nm}$ and NPs $>200 \mathrm{~nm}$ having the equivalent content of $\mathrm{Ca}^{2+}$. Each condition was tested in triplicate at $24 \mathrm{~h}$ and $48 \mathrm{~h}$ of culture, being MTT and Alamar Blue assays were employed to determine cell viability.

\section{MTT Viability Assay}

Cell proliferation was evaluated using a filtered (through a $0.2 \mu \mathrm{m}$ filter) MTT solution $(1 \mathrm{mg} / \mathrm{mL}$ in phosphate buffer saline (PBS) of $\mathrm{pH}$ 7.4). Then, a mixture of $50 \mu \mathrm{L}$ of MTT and $200 \mu \mathrm{L}$ of DMEM without phenol red were added into each well of a 96-well plate (except cell-free blank wells). The plate was incubated for $4 \mathrm{~h}$ under culture conditions. Finally, the MTT solution was removed and replaced with $200 \mu \mathrm{L}$ of DMSO and $25 \mu \mathrm{L}$ of Sorenseńs glycine buffer (0.1 M glycine, $0.1 \mathrm{M} \mathrm{NaCl}, \mathrm{pH} 10.5$ after being adjusted with $0.1 \mathrm{M} \mathrm{NaOH})$. The plate was maintained for $5 \mathrm{~min}$ at room temperature, and the optical density (OD) of each well was quantified by spectrophotometry using a plate reader (XMark $^{\mathrm{TM}}$ Microplate Absorbance Spectrophotometer, Bio-Rad) at $570 \mathrm{~nm}$.

\section{Alamar Blue Viability Assay}

The determination of metabolic activity using this assay is based on the mitochondrial hydrolase activity. The assay was performed according to the manufactureŕs protocol. Cells were treated with $10 \%$ Alamar blue solution and kept at $37{ }^{\circ} \mathrm{C}$ for $2 \mathrm{~h}$. Red fluorescence resulting from the reduction of Alamar blue was monitored (excitation/emission: 553/590) by spectrophotometry using a plate reader (XMark $^{\mathrm{TM}}$ Microplate Absorbance Spectrophotometer, Bio-Rad).

\section{Results and Discussion}

\section{Characterization of ACP}

The morphology of ACP, which is displayed in Fig. 1a and $b$, reflect the influence of hydrothermal and aging conditions. ACP particles obtained using open aging, exhibit an pseudo-spherical morphology of nanometric dimensions. The average dimensions of ACP pseudo-spheres are displayed in Table 2.

Characterization of synthesized particles by X-ray diffraction (Fig. 1c) was focused on peaks at $2 \theta$ between $31.5^{\circ}$ and $34.5^{\circ}$, which correspond to the (211), (112), and (300) hydroxyapatite reflections. The crystallinity and crystallite size determined for ACP samples are listed in Table 2.

\section{Experimental Detection of Adsorption Onto ACP}

The FTIR spectra of the synthesized ACP, polyP, $\mathrm{P}_{2} \mathrm{O}_{7}^{4-}$ and ATMP are displayed in Fig. 2a while the most characteristic bands of each compound are listed in Table 1. It should be noted that the asymmetric and symmetric stretching vibration of the $\mathrm{P}-\mathrm{O}-\mathrm{P}$ bridges are characteristic of polyP and $\mathrm{P}_{2} \mathrm{O}_{7}^{4-}$, even though they are not observed for ACP. The $\mathrm{PO}_{3}^{2-}$ vibration modes of polyP and $\mathrm{P}_{2} \mathrm{O}_{7}^{4-}$ are detected in 1000-1200 $\mathrm{cm}^{-1}$ domain, as detailed in 
(a)

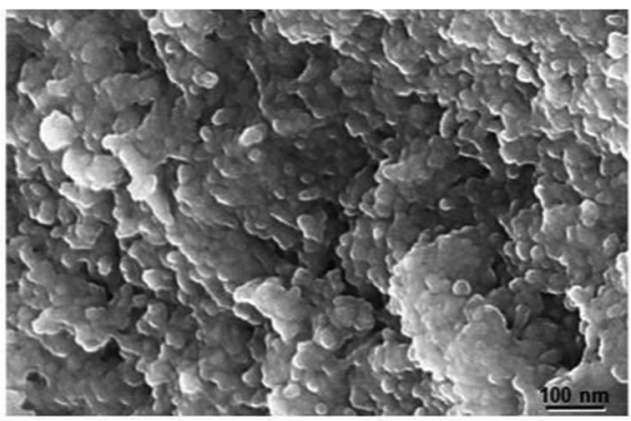

(b)

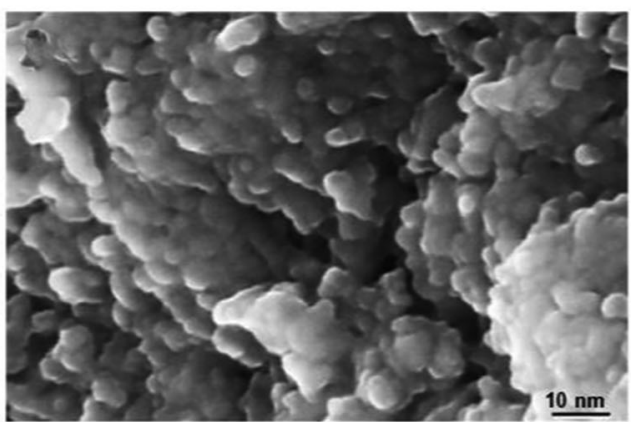

(c)

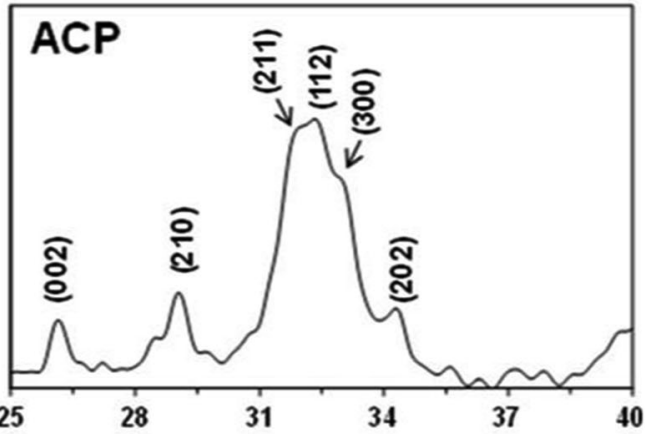

Fig. 1 Morphology and X-ray diffraction patterns of the ACP nanoparticles prepared in this work. a and b show low and high resolution SEM micrographs respectively. The hydroxyapatite was identified by the peaks at $33^{\circ}-34^{\circ} 2 \theta$

previous work [26]. On the other hand, the ATMP spectrum was recently described by some of us [27].

Figure $2 \mathrm{~b}$ displays the FTIR spectra of ACP recorded after incubation in solutions which contained $12.5 \mathrm{mM}$ of polyP, $\mathrm{P}_{2} \mathrm{O}_{7}^{4-}$ and ATMP at neutral $\mathrm{pH}$. For polyP the characteristic absorption band is clearly identified at around $891-894 \mathrm{~cm}^{-1}$. The band at $734 \mathrm{~cm}^{-1}$ is also detectable. Regarding the adsorption of $\mathrm{P}_{2} \mathrm{O}_{7}^{4-}$, a very weak shoulder associated to the band at $889 \mathrm{~cm}^{-1}$ is observed while, in opposition, the band at $736 \mathrm{~cm}^{-1}$ remains practically undetectable. Although these results evidence the adsorption of polyP and $\mathrm{P}_{2} \mathrm{O}_{7}^{4-}$, difficulties in the identification of some characteristic bands suggest some limitations in such association processes. Finally the adsorption of ATMP, the shoulder detected at $\sim 900 \mathrm{~cm}^{-1}$ transforms into a broad but weak band.

The ability of ACP to bind polyP and $\mathrm{P}_{2} \mathrm{O}_{7}^{4-}$ has been corroborated by XPS. Figure $2 \mathrm{c}$ represents the characteristic XPS spectra in the O1s region of ACP as prepared and after incubation in presence of polyP, $\mathrm{P}_{2} \mathrm{O}_{7}^{4-}$ and ATMP (all solutions at $12.5 \mathrm{mM}$ ). The sharp peak at $531.2 \mathrm{eV}$ involve in all cases to the $\mathrm{O} 1 \mathrm{~s}$ of the $\mathrm{PO}_{4}^{3-}$ and $\mathrm{OH}^{-}$groups of ACP [28]. The spectra of samples incubated in presence of polyP and $\mathrm{P}_{2} \mathrm{O}_{7}^{4-}$ show a shoulder at $533.3 \mathrm{eV}$, which corresponds to the oxygen atom involved in symmetric bridging P-O-P groups of the adsorbed molecules [29]. This result supports the adsorption previously detected by FTIR spectroscopy. Finally, the broad peak at $536.3 \mathrm{eV}$, which is only detected in samples with adsorbed polyP and $\mathrm{P}_{2} \mathrm{O}_{7}^{4-}$, can be attributed to non-bridging oxygen atoms [30], water accompanying the adsorbed compounds [31] or a combination of both.

\section{Microinjection of ACP Into Living Cells}

The intracellular effect of $\mathrm{Ca}^{2+}$ is still one of the most discussed aspects in the area of cellular physiology. This effect has relevant importance in the processes of cellular transfection, such as a non-viral transport of biomacromolecules. A typical intracellular level of $\mathrm{Ca}^{2+}$ is around 50-100 nM [32]. However, variations in cytosolic $\mathrm{Ca}^{2+}$ free levels may be of great relevance in health. Transient increments in cytosolic $\mathrm{Ca}^{2+}$ concentration occur during the cell cycle (i.e. at the late $\mathrm{G}_{1}$ prior to the initiation of the $S$ phase and later on during $G_{2}$ before entry into $M$ phase) $[33,34]$.

In the case of ACP nanoparticles uptake, a strong disturbance in cytosolic $\mathrm{Ca}^{2+}$ concentration may influence the progression of the cell cycle. A sharp increase in cytosolic $\mathrm{Ca}^{2+}$ concentration without any recovery can be associated with cell death. On the contrary, cells survived when they were able to decrease the cytosolic $\mathrm{Ca}^{2+}$ concentration to the baseline level [35]. In this study, we analyze the intracellular incorporation pathway of $\mathrm{Ca}^{2+}$ and calcium contained in the two amorphous calcium phosphate
Table 2 Physical parameters as determined by SEM and X-ray diffraction for ACP

\begin{tabular}{ll}
\hline & ACP \\
\hline Average radius $(R)$ and length $(\ell)$ of the observed nanostructures & $R=2.6 \pm 0.2 \mathrm{~nm}$ \\
Cristallinity (see Eq. 1) & $\chi_{c}=3 \pm 1 \%$ \\
Crystallite size (see Eq. 2) & $L=6 \pm 1 \mathrm{~nm}$ \\
\hline
\end{tabular}




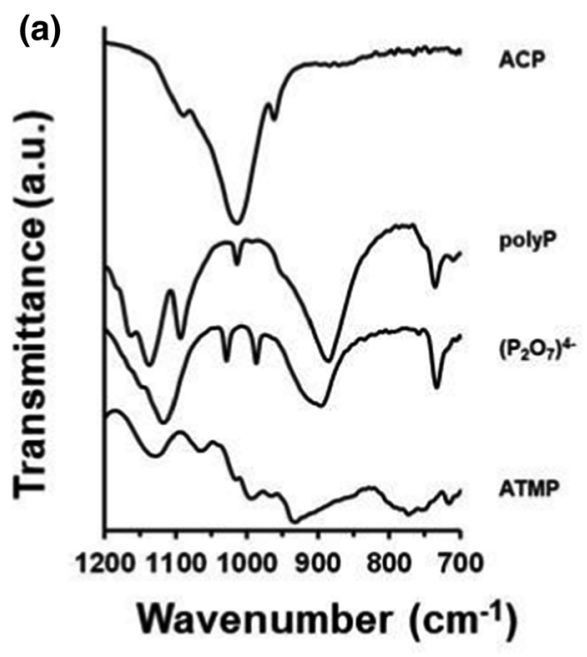

(b)
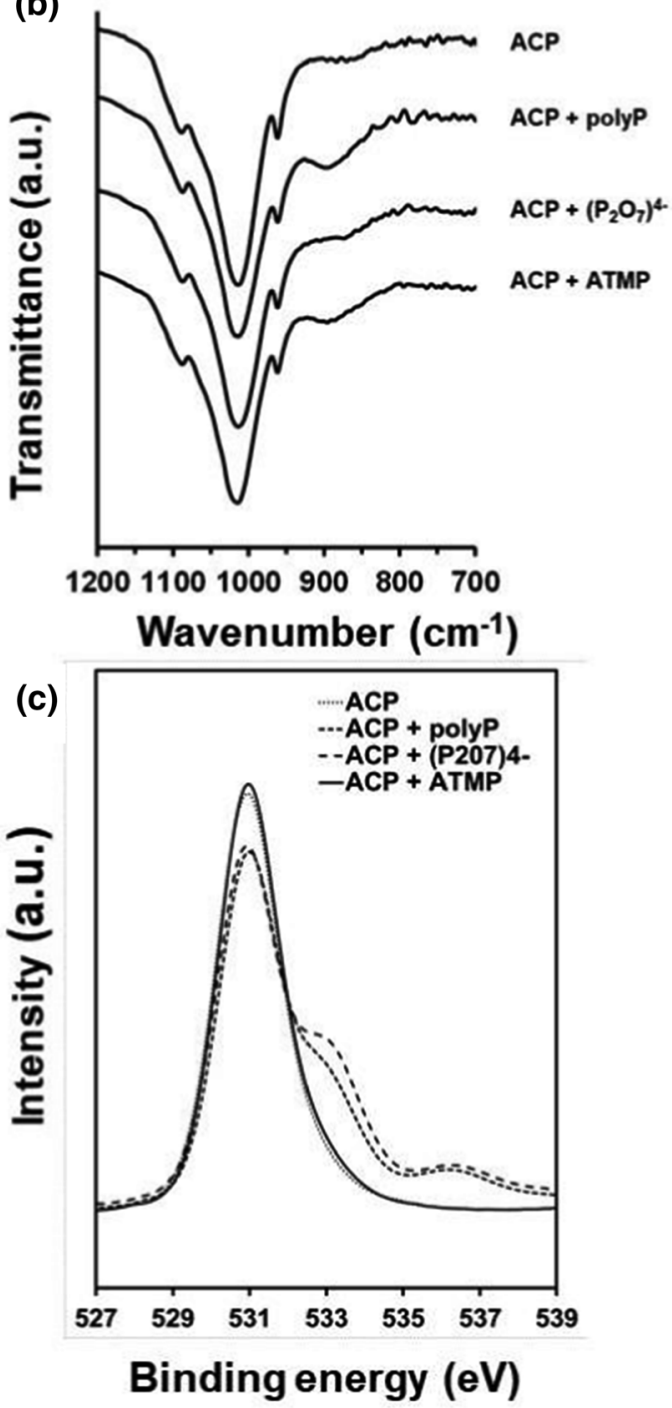

4Fig. 2 FTIR and XPS spectra of the ACP nanoparticles prepared in this work a FTIR spectra of ACP, polyP, $\mathrm{P}_{2} \mathrm{O}_{7}^{4-}$ and ATMP; b FTIR spectra of ACP samples incubated in working aqueous solutions which contained $12.5 \mathrm{mM}$ of polyP, $\mathrm{P}_{2} \mathrm{O}_{7}^{4-}$ and ATMP; and c Highresolution XPS spectra in the O1s region for ACP samples before and after incubation in presence of polyP (12.5 mM; top), $\mathrm{P}_{2} \mathrm{O}_{7}^{4-}$ (12.5 mM; middle) and ATMP (12.5 mM; bottom) at $\mathrm{pH} 7.4$

nanoparticle fractions (i.e. NPs $<200 \mathrm{~nm}$ and NPs $>200$ $\mathrm{nm})$. Epithelial-type, fibroblast-type and endothelial-type cells (MCF-7, COS-1 and HUVEC cells, respectively) were considered to get more generalist conclusions.

The study was initiated with an analysis of the timecourse of $\mathrm{Ca}^{2+}$ and NPs microinjected into the MCF-7, COS- 1 and HUVEC cells to demonstrate unequivocally the direct effect of $\mathrm{Ca}^{2+}$ and NPs (Fig. 3a). For the microinjected $\mathrm{Ca}^{2+}(\sim 400 \mathrm{nM})$, a progressive reduction of the intracellular $\mathrm{Ca}^{2+}$ concentration up to $\sim 50 \%$ was observed after $24 \mathrm{~h}$ of its microinjection. On the contrary, for the microinjected NPs (equivalent to $\sim 400 \mathrm{nM}$ of $\mathrm{Ca}^{2+}$ ), a rapid release of free $\mathrm{Ca}^{2+}$ was observed and corresponded to $100 \mathrm{nM}$ (time $0 \mathrm{~h}$, at the beginning of the experiment). These measurements were possible because the indicator Fura-2 is a ratiometric and sensitive dye for measuring intracellular $\mathrm{Ca}^{2+}$. The time-course of $\mathrm{Ca}^{2+}$ contained in NPs showed a progressive increase in the intracellular $\mathrm{Ca}^{2+}$ concentration, demonstrating the occurrence of $\mathrm{Ca}^{2+}$ release from NPs injected into the cell cytoplasm. Thus, it was determined that after $24 \mathrm{~h}$ of the microinjection of NPs $<200 \mathrm{~nm}$ and NPs $>200 \mathrm{~nm}$, the intracellular $\mathrm{Ca}^{2+}$ concentration was $\sim 200 \mathrm{nM}$ and $\sim$ $150 \mathrm{nM}$, respectively (Fig. 3a). An observation that stands out from these pulse-chase experiments is the similar behavior of HUVEC, COS- 1 and MCF-7 cells.

\section{Analysis of Surface Blebs in Cells Incorporating ACP}

On the other hand, the cytotoxic effect caused by different concentrations of $\mathrm{Ca}^{2+}$ and NPs were also evaluated (Fig. 3b). The cytotoxicity was followed by the formation of cytoplasmic blebs. For microinjected $\mathrm{Ca}^{2+}$, a severe dose-dependent cytotoxic damage was observed. The highest microinjected dose $(800 \mathrm{nM})$ caused a cell damage of $70-80 \%$ for the three cell types treated (i.e. HUVEC, COS-1 and MCF-7 cells). However, intracellular $\mathrm{Ca}^{2+}$ doses in the range of $100-400 \mathrm{nM}$ shown a cytotoxic damage that was dependent on the cell type. Thus, endothelial HUVEC cells were the most sensitive (i.e. $40 \%$ of blebs) when the intermediate intracellular dose of $400 \mathrm{nM} \mathrm{Ca}^{2+}$ was applied. On the contrary, epithelial MCF-7 cells were less sensitive (i.e. $15 \%$ of blebs), while 
(a) $\mathrm{Ca}^{+2}$

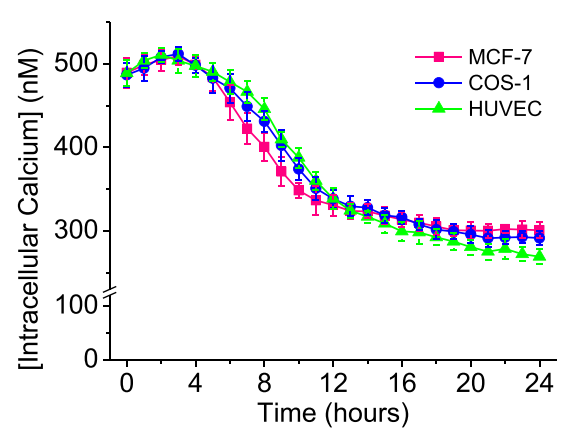

(b)

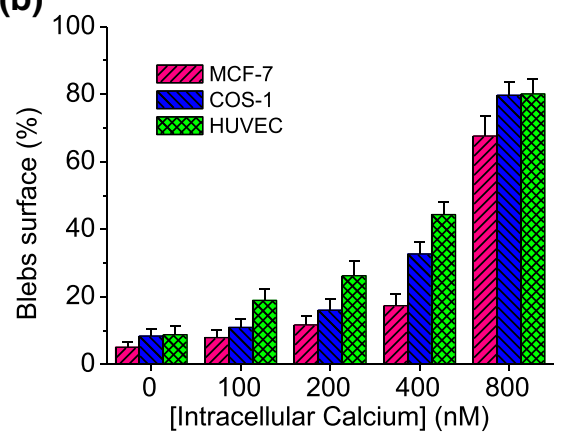

NPs $<200 \mathrm{~nm}$
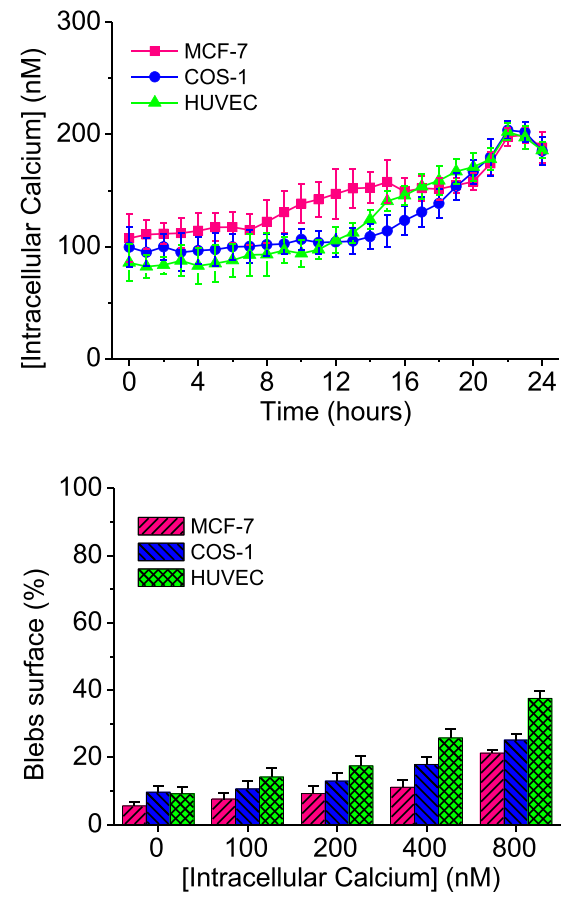

NPs $>200 \mathrm{~nm}$
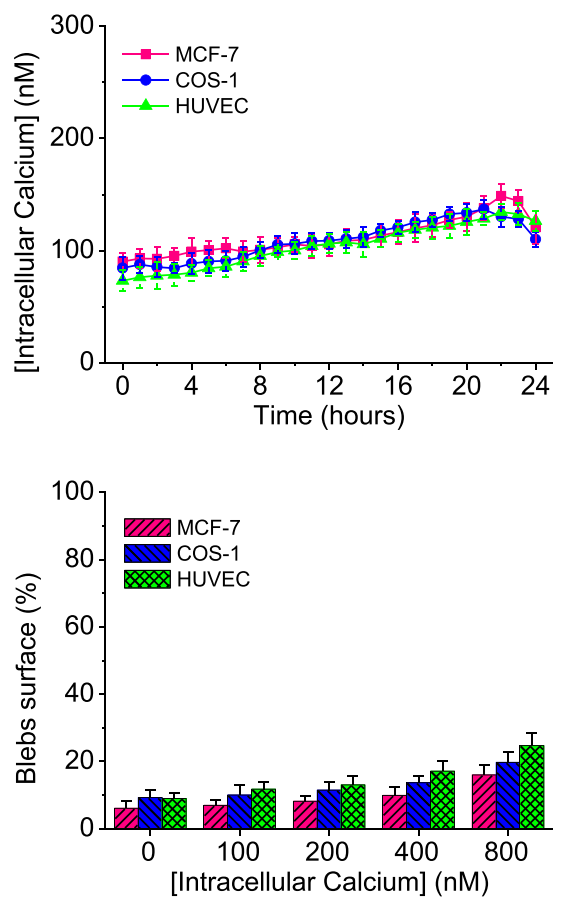

Fig. 3 Time-course and cytotoxic effect of the intracellular $\mathrm{Ca}^{2+}$, NPs $<200 \mathrm{~nm}$ and NPs $>200 \mathrm{~nm}$ microinjected into MCF-7, COS-1 and HUVEC cells. a Changes in cytoplasmic $\mathrm{Ca}^{2+}$ concentration after microinjection of $400 \mathrm{nM} \mathrm{Ca}^{2+}$ or their equivalent content in the case

COS-1 fibroblasts showed an intermediate cytotoxicity (i.e. $30 \%$ of blebs). A similar behavior was observed when NPs were microinjected, but the cytotoxic damage was smaller. Thus, the intracellular doses of NPs equivalent to $800 \mathrm{nM}$ $\mathrm{Ca}^{2+}$ only produced a cellular damage close to $30-40 \%$ and $25-35 \%$ of blebs for the microinjection of NPs $<$ $200 \mathrm{~nm}$ and NPs $>200 \mathrm{~nm}$, respectively. This cytotoxic effect of the NPs was again related to the lower availability of $\mathrm{Ca}^{2+}$, since ions appear structured or bounded with the phosphate groups of the formed amorphous NPs.

Moreover, these results demonstrated the dependence of the cytotoxicity on the cellular type but more interestingly on their origin, or genetic condition. By contrast, HUVEC endothelial cells, which are derived from primary cultures and, therefore, can be considered normal, were the most sensitive to cytotoxic damage. Intermediate effect was observed with COS-1 fibroblasts, which are transformed cells by genetic modification, through the incorporation of SV40 particles.

\section{Analysis of Cell Viability in Cells Incorporating ACP by Alamar Blue and MTT Assays}

Figure 4 shows the viability results of cells exposed to different concentrations of $\mathrm{Ca}^{2+}$ and NPs. In these of NPs. $\mathrm{Ca}^{2+}$ concentrations are relative to the control (physiological concentration $\sim 100 \mathrm{nM}$ ). b Vesicular surface (blebs percentage) after microinjection of different concentrations of $\mathrm{Ca}^{2+}$ or their equivalent content in the case of NPs

experiments the cellular incorporation of $\mathrm{Ca}^{2+}$ was performed through a non-electroporation (-EP) diffusion process (Fig. 4a) and also by electrophoretic mobilization (i.e. electroporation (+ EP)) (Fig. 4b). The inhibition of the effect of $\mathrm{Ca}^{2+}$-free and $\mathrm{Ca}^{+2}$ released from NPs has been produced by its chelation using EGTA in both treatments ( $-\mathrm{EP}$ and $+\mathrm{EP})$. In these experiments are highly remarkable that the MCF-7 epithelial cells derived from adenocarcinoma were the most resistant to the cytotoxic effect of $\mathrm{Ca}^{2+}$.

Figure 4a clearly shows that during the $-\mathrm{EP}$ process the different concentrations of $\mathrm{Ca}^{2+}$-free and $\mathrm{Ca}^{2+}$ chelated with EGTA (in the range of 0-3.2 mM) have not effect on the viability of the three cell types (HUVEC, COS- 1 and MCF-7). These results highlight that the entry of $\mathrm{Ca}^{2+}$ inside cells is an active transport through the cell membrane. Plasma membrane channels support the entry into cells of $\mathrm{Ca}^{2+}$ due to the gradient concentration driven process. Various calcium channels, such as voltage-gated $\mathrm{Ca}^{2+}$ channels $\left(\mathrm{Ca}_{\mathrm{v}}\right.$ family), can be involved in this $\mathrm{Ca}^{2+}$ influx. The expression of this family of proteins is a characteristic of "excitable cells" and these channels require depolarization of the plasma membrane for their activation [36]. 

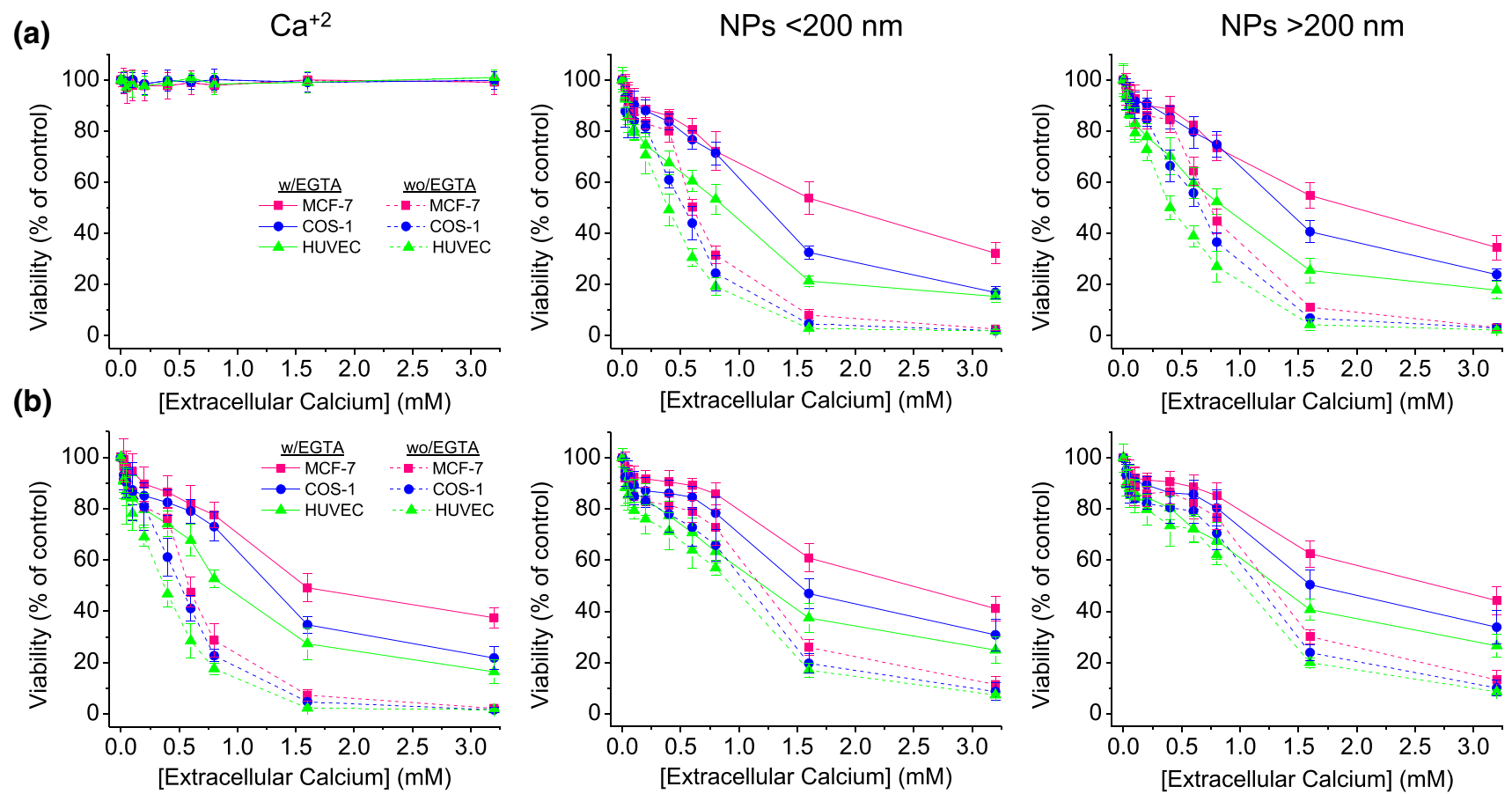

Fig. 4 Viability of MCF-7, COS-1 and HUVEC cells treated with extracellular $\mathrm{Ca}^{2+}$ and NPs $<200 \mathrm{~nm}$ and NPs $>200 \mathrm{~nm}$ by a nonelectroporation ( $-\mathrm{EP})$ and $\mathbf{b}$ electroporation $(+\mathrm{EP}) . \mathrm{Ca}^{+2}$ concentrations in the range of 0 to $3.2 \mathrm{mM}$ were considered in the presence and

Despite $\mathrm{Ca}_{\mathrm{v}}$ expression, $\mathrm{Ca}^{2+}$ entry in non-excitable cells mostly occurs through non-voltage gated channels. These include ligand-gated channels (e.g. P2X purinergic ionotropic receptor families), receptor-operated channels (ROC), secondary messenger-operated channels linked to GPCR activation, store-operated and stretch-operated channels. Numerous studies have shown that one or several $\mathrm{Ca}^{2+}$-permeable channels in the plasma membrane are modified in expression and/or activity in different cancer cells, and play a role in most of the pathophysiological processes driving the malignant phenotype. In addition to the plasma membrane $\mathrm{Ca}^{2+}$ channels, changes in $\mathrm{Ca}^{2+}$-transporters such as plasma membrane $\mathrm{Ca}^{2+}$. ATPase and $\mathrm{Na}^{+} / \mathrm{Ca}^{2+}$ exchanger have also been reported to be involved in the $\mathrm{Ca}^{2+}$ homeostasis of cancer cells and in tumorigenesis $[37,38]$. Finally, it should be considered that the entry of $\mathrm{Ca}^{2+}$ ions into cells is a biological event regulated in a highly complex manner that does not depend exclusively on its gradient as can be seen in Fig. 4a for $\mathrm{Ca}^{2+}$-free experiments.

On the other hand, the forced incorporation of $\mathrm{Ca}^{+2}$-free by + EP (Fig. 4b) caused clear cytotoxic effects. The sensitivity of cells was in the order HUVEC $>$ COS$1>$ MCF-7 with $\mathrm{CC}_{50}$ of $0.37,0.51$ and $0.58 \mathrm{mM}$, respectively (Table 3 ). In addition, this cytotoxic effect can clearly be inhibited when the $\mathrm{Ca}^{+2}$ was chelated, being logically the $\mathrm{CC}_{50}$ values higher (i.e. $0.88,1.27$ and absence of $0.5 \mathrm{mM}$ EGTA as chelating agent. Cellular viability was measured with the Alamar Blue reagent after $24 \mathrm{~h}$ of culture

$1.56 \mathrm{mM}$ for HUVEC, COS-1 and MCF-7, respectively) (Table 3). In this study, we have introduced EGTA-AM into cells, which became active after cleaving the acetoxymethylester (AM) by intracellular esterases. The released EGTA free acid was able to chelate intracellular $\mathrm{Ca}^{2+}$. Results about $\mathrm{CC}_{50}$ changes were relevant and demonstrated the chelating effect of EGTA and that $\mathrm{Ca}^{2+}$ ions were responsible of triggering the cell death. The HUVEC endothelial cells were the most sensitive, followed by the COS- 1 fibroblast cells, and finally by the MCF-7 epithelial cells.

However, both NPs $<200 \mathrm{~nm}$ and NPs $>200 \mathrm{~nm}$ showed similar dose-response effects under -EP conditions for viability of the different cell types. Figure $4 \mathrm{a}$ and Table 3 show that the $\mathrm{CC}_{50}$ for the NPs $<200 \mathrm{~nm}$ were $0.40,0.53$ and $0.60 \mathrm{mM}$ for HUVEC, COS- 1 and MCF-7 cells, respectively. In addition, these $\mathrm{CC}_{50}$ values increased to $0.88,1.24$ and $1.87 \mathrm{mM}$ for HUVEC, COS-1 and MCF-7 cells, respectively, after $\mathrm{Ca}^{2+}$ chelation. A similar situation was observed for NPs $>200 \mathrm{~nm}$ with $\mathrm{CC}_{50}$ values of 0.40 , 0.65 and $0.75 \mathrm{mM}$, which after chelation increased to 0.83 , 1.33 and $1.82 \mathrm{mM}$, for HUVEC, COS-1 and MCF-7 cells, respectively. These results suggest three clear features when the cells were exposed to NPs $<200 \mathrm{~nm}$ and NPs $>200 \mathrm{~nm}$ : (1) Similar cytotoxic effects were observed due to their ability to release $\mathrm{Ca}^{2+}$ into cells, being this effect inhibited by chelation with intracellular 
Table $3 \mathrm{CC}_{50}$ of $\mathrm{Ca}^{2+}$ and NPs incorporated into cells by electroporation (+EP) and nonelectroporation (-EP). Experiments were performed with and without $\mathrm{Ca}^{2+}$ chelation (i.e. +EGTA and -EGTA, respectively)

\begin{tabular}{|c|c|c|c|c|c|c|}
\hline \multirow[t]{3}{*}{ Cell line } & \multicolumn{6}{|c|}{$\mathrm{CC}_{50}(\mathrm{mM})$} \\
\hline & \multicolumn{2}{|l|}{$\mathrm{Ca}^{2+}$} & \multicolumn{2}{|c|}{$\mathrm{NPs}<200 \mathrm{~nm}$} & \multicolumn{2}{|c|}{ NPs $>200 \mathrm{~nm}$} \\
\hline & -EGTA & + EGTA & -EGTA & + EGTA & -EGTA & +EGTA \\
\hline \multicolumn{7}{|l|}{-EP } \\
\hline MCF-7 & - & - & 0.60 & 1.87 & 0.75 & 1.82 \\
\hline COS-1 & - & - & 0.53 & 1.24 & 0.65 & 1.33 \\
\hline HUVEC & - & - & 0.40 & 0.88 & 0.40 & 0.83 \\
\hline \multicolumn{7}{|l|}{$+\mathrm{EP}$} \\
\hline MCF-7 & 0.57 & 1.56 & 1.19 & 2.46 & 1.25 & 2.65 \\
\hline COS-1 & 0.51 & 1.27 & 1.07 & 1.51 & 1.15 & 1.60 \\
\hline HUVEC & 0.37 & 0.88 & 0.94 & 1.22 & 1.02 & 1.32 \\
\hline
\end{tabular}

EGTA; (2) The occurrence of these cytotoxic effects has as a prerequisite that the NPs were internalized into the cells. The endocytosis pathway seems the most plausible via for -EP treatment; and (3). The endothelial HUVEC cells and the epithelial MCF-7 cells were the most and the least sensitive, respectively.

$\mathrm{CC}_{50}$ values were higher under $+\mathrm{EP}$ conditions for both released and chelated $\mathrm{Ca}^{2+}$ (Fig. 4b and Table 3). Thus, the $\mathrm{CC}_{50}$ values for HUVEC, COS-1 and MCF-7 cells exposed to the NPs $<200 \mathrm{~nm}$ were $0.94,1.07$ and $1.19 \mathrm{mM}$, respectively, for the released $\mathrm{Ca}^{2+}$, and 1.22, 1.51 and 2.46 for the chelated $\mathrm{Ca}^{2+}$. Highly similar values were obtained when HUVEC, COS-1 and MCF-7 cells were exposed to $\mathrm{NPs}>200 \mathrm{~nm}$. In this case, the $\mathrm{CC}_{50}$ values were 1.02 , 1.15 and $1.25 \mathrm{mM}$, respectively, for released $\mathrm{Ca}^{2+}$, and 1.32, 1.60 and $2.65 \mathrm{mM}$ for chelated $\mathrm{Ca}^{2+}$. These higher $\mathrm{CC}_{50}$ values can be explained taking into account that $+\mathrm{EP}$ fluidizes the plasma membrane and allows increases in the mobility of NPs as consequence of their electrical charge. Therefore, NPs cannot form vesicles and, therefore, the release of $\mathrm{Ca}^{2+}$ becomes smaller and higher concentration of NPs is required to achieve the $\mathrm{CC}_{50}$. In general, the cytotoxic effect caused by $+\mathrm{EP}$ is lower than the one produced by -EP. The incorporated NPs are not vesiculated and, consequently, cannot reach pathways such as vesicle fusion, fusion with lysosomes or other cellular compartments when electroporation was applied.

In this study, viability was evaluated by the cells metabolic activity through the conversion of Alamar blue reagent by mitochondrial NADPH-oxidoreductase enzymes of viable cells after $24 \mathrm{~h}$ of culture (Fig. 4). Similar results were attained after prolonging cell cultures for $48 \mathrm{~h}$ (Mat. Suppl., Figure S1 and Table S1). Additionally, cell viability was determined by the MTT reagent, which is based on the metabolic activity mediated by mitochondrial and lysosomal NADPH-dehydrogenases of the viable cells, after $24 \mathrm{~h}$ and $48 \mathrm{~h}$ of culture (Mat. Suppl., Figure S2, S3, S4 and Table S2, S3). Cell viability was found to be similar by applying both methodologies. Finally, the cytotoxic damage caused by ACP NPs could be related to their disposition to release $\mathrm{Ca}^{2+}$ (e.g. from the endocytic vesicles via fusion with lysosomes and from the cytoplasmic aggregate via dissolution). The increase in intracellular concentration of $\mathrm{Ca}^{2+}$ produced cell injury through the mitochondrial damage (Fig. 5).

\section{Analysis of Cell Viability in Cells Incorporating ACP Incubated in Presence of polyP, $\mathrm{P}_{2} \mathrm{O}_{7}^{4-}$ and ATMP by Alamar Blue and MTT Assays}

Recently, we have prepared modified ACP nanoparticles by adsorption of polyphosphates (polyP), orthophosphate $\left(\left(\mathrm{P}_{2} \mathrm{O}_{7}\right)^{4-}\right)$ and phosphonate (ATMP) [39]. These surface modifications of the ACP NPs had an influence on their different physical and chemical characteristics (e.g. solubility). Interestingly, these surface modifications of ACP NPs can be reversed in some cases after specific treatments as it has been explored in this work. Thus, treatment with alkaline phosphatase in the presence of $\mathrm{Mg}^{2+}$ as cofactor can eliminate the adsorbed coating of orthophosphate and polyphosphates [39, 40]. Figure 6 displays the SEM micrographs of these synthesized nanoparticles. In all the cases we may observe poor dispersion and subsequent aggregation. Although dispersed nanoparticles could be obtained using hydrotermal conditions (20 Torr and 150 degrees $\mathrm{C}$ ), we use ACP because is the first precipitate when adding $\mathrm{Ca}^{2+}$ solutions to phosphate aqueous solutions in physiological conditions [41].

In general, NPs coated with polyP, ATMP and $\left(\mathrm{P}_{2} \mathrm{O}_{7}\right)^{4-}$ showed a similar behavior than NPs without modification when they were incorporated into the cells by -EP and + EP. Thus, HUVEC and MCF-7cells were the most and least sensitive, respectively. In all cases, $\mathrm{CC}_{50}$ values were higher when the incorporation of the NPs was performed with +EP compared to -EP (Fig. 7a, Table 4). However, it is remarkable that the NPs with modified surfaces and 


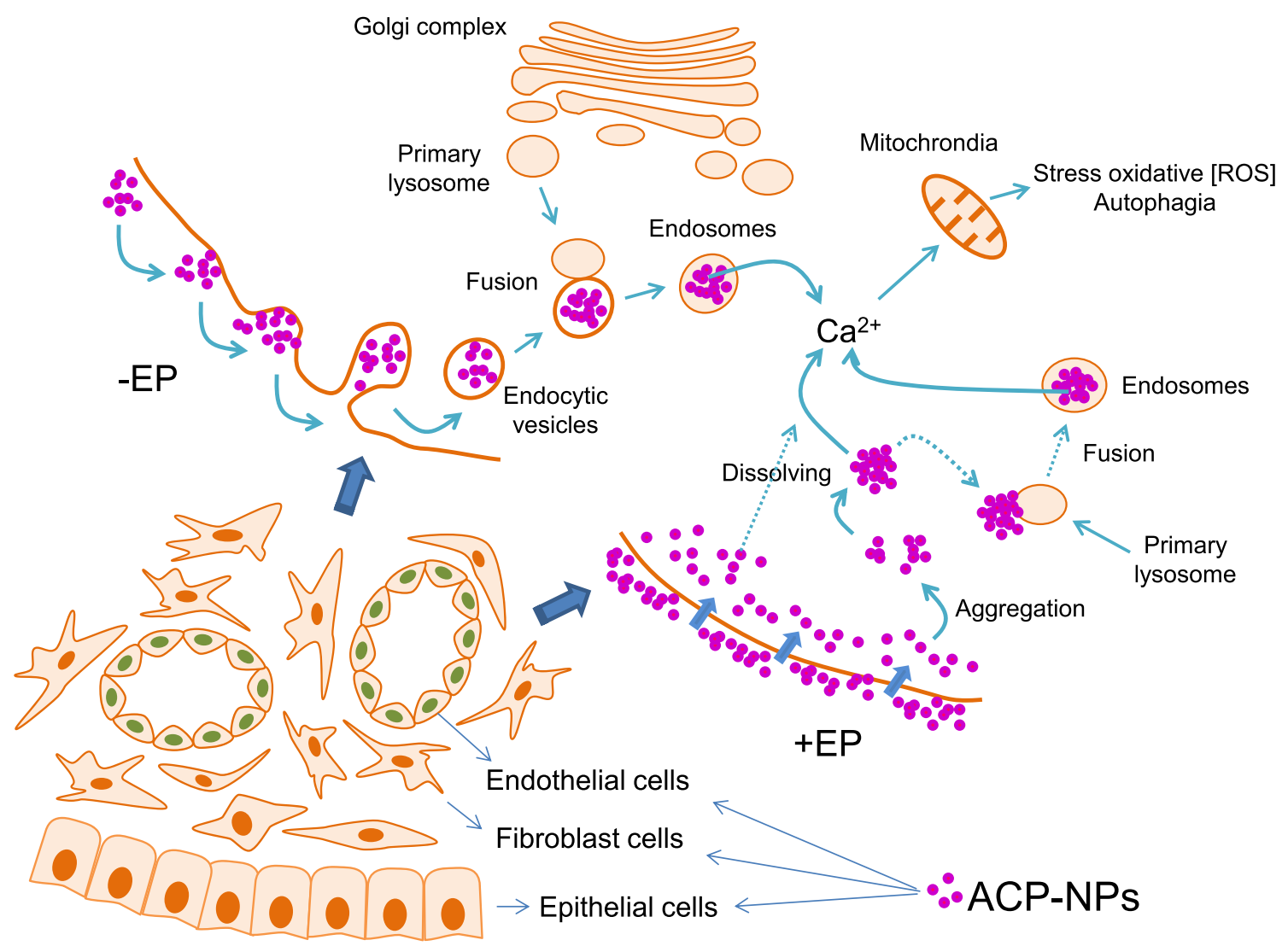

Fig. 5 Scheme of biological events relative to the cytotoxic effect of the intracellular $\mathrm{Ca}^{2+}$, NPs $<200 \mathrm{~nm}$ and NPs $>200 \mathrm{~nm}$ microinjected into MCF-7, COS-1 and HUVEC cells

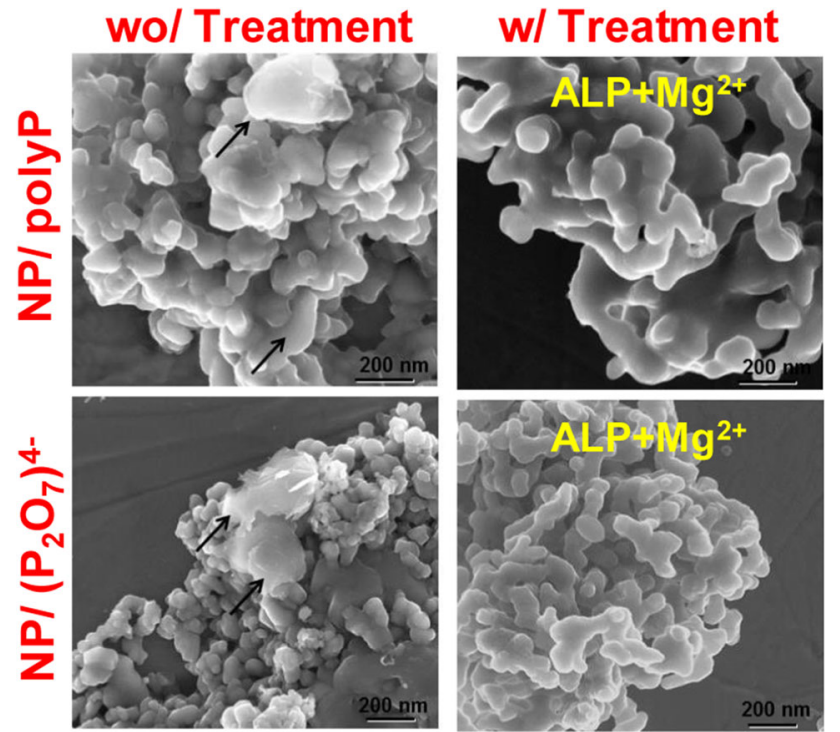

Fig. 6 Morphology of NPs modified by adsorption of biophosphates under SEM. Specific treatments with alkaline phosphatase (ALP) and $\mathrm{Mg} 2+$ as cofactor were applied to remove biophosphate coatings, respectively

incorporated by -EP were less cytotoxic than NPs without modification. Thus, $\mathrm{CC}_{50}$ values of $0.85,0.68$ and
$0.52 \mathrm{mM}$ were determined for HUVEC cells treated with NPs coated with polyP, ATMP and $\left(\mathrm{P}_{2} \mathrm{O}_{7}\right)^{4-}$, respectively. By contrast, the $\mathrm{CC}_{50}$ values of NPs without surface modification were $0.39 \mathrm{mM}$. In addition, the same order of cell damage as a function of the coating (polyP $<$ ATMP $<\left(\mathrm{P}_{2} \mathrm{O}_{7}\right)^{4-}$ ) was observed for COS-1 and MCF-7 cells with the -EP treatment (Table 2). On the other hand, when the modified NPs were incorporated by $+\mathrm{EP}$, the $\mathrm{CC}_{50}$ values were observed in the range of $1.0-1.3 \mathrm{mM}$ without significant differences between the distinct NPs surface coatings (Table 2).

The treatment with alkaline phosphatase and the $\mathrm{MgCl}_{2}$ cofactor of the superficially modified NPs resulted in a successful removal of polyP and $\left(\mathrm{P}_{2} \mathrm{O}_{7}\right)^{4-}$ modifications [42]. Thus, the $\mathrm{CC}_{50}$ values of NPs incorporated by $-\mathrm{EP}$ were similar to the $\mathrm{CC}_{50}$ values of the unmodified NPs (e.g. $\mathrm{CC}_{50}$ values for HUVEC cells incorporating NP/polyP and $\mathrm{NP} /\left(\mathrm{P}_{2} \mathrm{O}_{7}\right)^{4-}$ were 0.43 and $0.42 \mathrm{mM}$, respectively (Table 4), which were close to the $0.39 \mathrm{mM}$ value determined for NPs without surface modification). Note that these values were clearly lower than those obtained before the enzymatic treatment (i.e. 0.85 and $0.52 \mathrm{mM}$, respectively). In addition, this situation occurred in a similar way for MCF-7 and COS-1 cells (Fig. 7b and Table 4). 
(a) MCF-7 cells

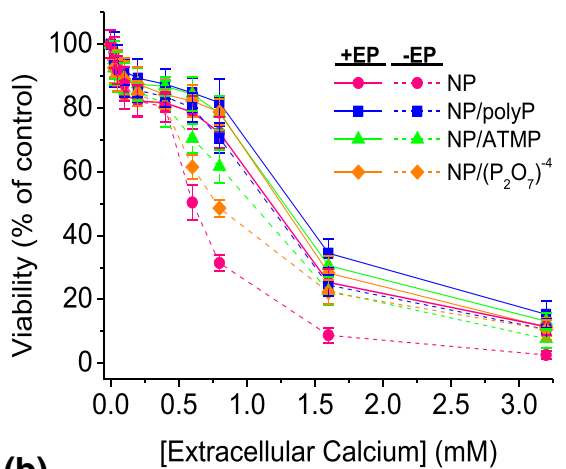

(b)

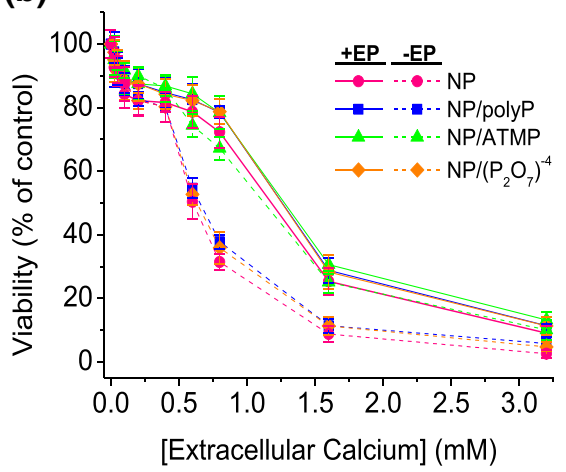

cos-1 cells
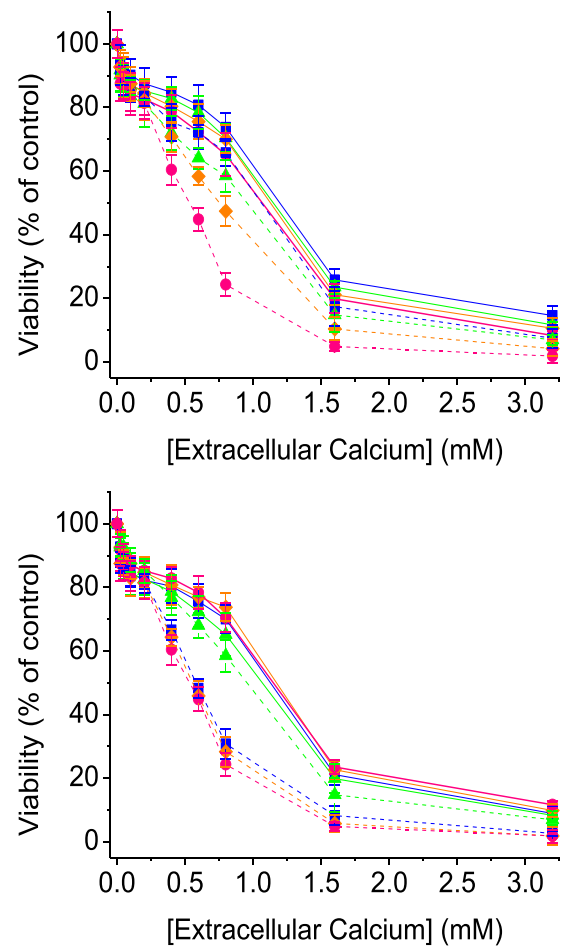

HUVEC cells
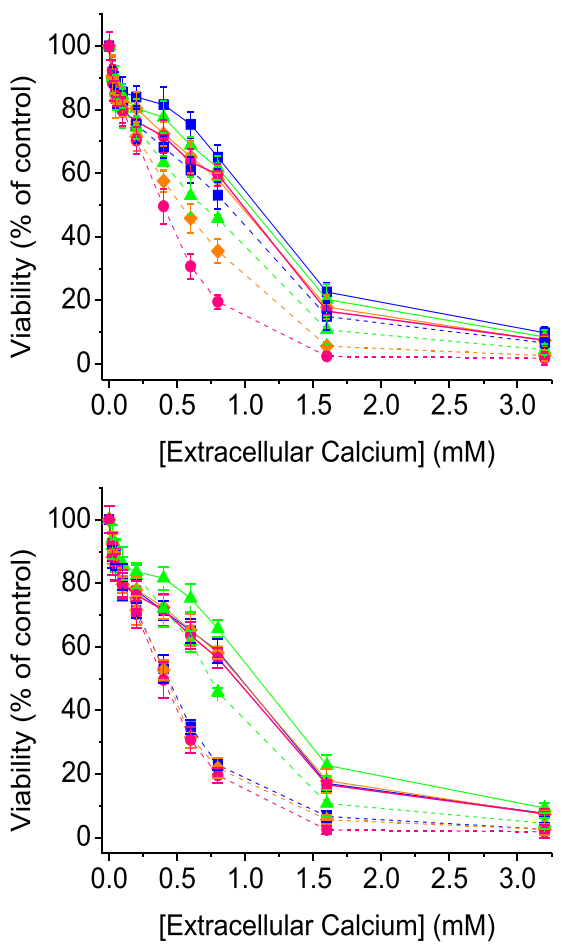

Fig. 7 Viability of MCF-7, COS-1 and HUVEC cells treated with NPs $<200 \mathrm{~nm}$ coated with biophosphates and biophosphonates. NPs with $\mathrm{Ca}^{+2}$ equivalent concentrations in the range of 0 to $3.2 \mathrm{mM}$ were incorporated by non-electroporation (-EP) and electroporation
$(+\mathrm{EP})$. Effect caused by coated NPs pre-treated with alkaline phosphatase alone (a) and together with $\mathrm{Mg}^{2+}$ as cofactor (b). The cellular viability was measured by Alamar Blue assay after $24 \mathrm{~h}$ of culture
Table $4 \mathrm{CC}_{50}$ of NPs $<200 \mathrm{~nm}$ coated with biophosphates and phosphonates. NPs were incorporated into cells by electroporation (+EP) and nonelectroporation (-EP). The effect was evaluated with and without any treatment

\begin{tabular}{|c|c|c|c|c|c|c|}
\hline \multirow[t]{3}{*}{ Nanoparticle } & \multicolumn{6}{|c|}{$\mathrm{CC}_{50}(\mathrm{mM})$} \\
\hline & \multicolumn{2}{|c|}{ MCF-7 } & \multicolumn{2}{|c|}{ COS-1 } & \multicolumn{2}{|c|}{ HUVEC } \\
\hline & $-\mathrm{EP}$ & $+\mathrm{EP}$ & $-\mathrm{EP}$ & $+\mathrm{EP}$ & $-\mathrm{EP}$ & $+\mathrm{EP}$ \\
\hline \multicolumn{7}{|l|}{ No-treatment } \\
\hline NP & 0.60 & 1.17 & 0.52 & 1.06 & 0.39 & 0.98 \\
\hline NP/polyP & 1.15 & 1.34 & 1.06 & 1.20 & 0.85 & 1.08 \\
\hline NP/ATMP & 1.03 & 1.28 & 0.95 & 1.15 & 0.68 & 1.02 \\
\hline $\mathrm{NP} /\left(\mathrm{P}_{2} \mathrm{O}_{7}\right)^{4-}$ & 0.77 & 1.25 & 0.75 & 1.12 & 0.52 & 0.96 \\
\hline \multicolumn{7}{|c|}{ Treatment: ALP $+\mathrm{MgCl}_{2}$} \\
\hline NP & 0.60 & 1.17 & 0.53 & 1.15 & 0.39 & 0.93 \\
\hline NP/polyP & 0.66 & 1.26 & 0.58 & 1.13 & 0.43 & 0.96 \\
\hline NP/ATMP & 1.13 & 1.28 & 0.95 & 1.06 & 0.74 & 1.10 \\
\hline $\mathrm{NP} /\left(\mathrm{P}_{2} \mathrm{O}_{7}\right)^{4-}$ & 0.64 & 1.26 & 0.55 & 1.18 & 0.42 & 0.95 \\
\hline
\end{tabular}

Finally, it is remarkable that the NPs incorporated by $+\mathrm{EP}$ and modified with the different coatings showed $\mathrm{CC}_{50}$ values with slight differences (e.g. see Table 4) after the enzymatic attack (Figures S5, S6 and Table S4). In summary, a constitutive and cumulative dissolution process took place and reached similar $\mathrm{Ca}^{2+}$ intracellular levels for all cell types. On the other hand, the endocytic pathway (-EP) of the different cell types demonstrates greater differential sensitivity to NPs without or with surface modification. In any case, the ability to release its $\mathrm{Ca}^{2+}$ content and exert cell injury that ends in the death of cells is demonstrated. 


\section{Conclusions}

Specific control of composition and size is one of the prime challenges in the synthesis of ACP, since such characteristics at the individual level determine the properties of the bulk dispersion and so the local damage in the living cell. ACP NPs have cytotoxic effects when internalized within cells. The endocytic pathway is more harmful than the incorporation by electroporation. The surface modification of ACP NPs and consequently the physical-chemical alteration (e.g. solubility decrease) of the NPs in subcellular compartments, such as lysosomes and mitochondria, decreased the severity of their cytotoxicity in the order polyphosphates $<$ ATMP $<$ orthophosphate. An interesting aspect that derives from this study is the differential cytotoxicity of the ACP NPs. Thus, it has been shown that epithelial-like MCF-7 cells were the most resistant to the effect of increased intracellular $\mathrm{Ca}^{2+}$ derived from ACP NPs, while endothelial-like HUVEC cells were the most sensitive and COS-1 cells fibroblasts-like showed an intermediate sensitivity. This result becomes significant if we consider the cellular organization of tissues as possible targets for treatment through the metabolic imbalance of calcium.

Supplementary Information The online version contains supplementary material available at https://doi.org/10.1007/s10876021-02182-6.

Acknowledgements This work was supported by B. Braun Surgical S.A. through a joint research agreement with UPC, and by the MINECO/FEDER (MAT2015-69367-R and MAT2015-69547-R) and the Agència de Gestió d'Ajuts Universitaris i de Recerca (2017SGR359 and 2017SGR373). Support for the research of C.A. was received through the prize "ICREA Academia" for excellence in research funded by the Generalitat de Catalunya. This work is integrated within a wider research project supported by B. Braun Surgical S.A., UPC and ICFO and H. Germans Trias i Pujol.

Funding Open Access funding provided thanks to the CRUE-CSIC agreement with Springer Nature. This work was supported by B. Braun Surgical S.A. through a joint research agreement with UPC, and by the MINECO/FEDER (MAT2015-69367-R and MAT201569547-R) and the Agència de Gestió d'Ajuts Universitaris i de Recerca (2017SGR359 and 2017SGR373). Support for the research of C.A. was received through the prize "ICREA Academia" for excellence in research funded by the Generalitat de Catalunya. This work is integrated within a wider research project supported by B. Braun Surgical S.A., UPC and ICFO and H. Germans Trias i Pujol.

Availability of Data and Material The authors declare that all data supporting the findings of this study are available within the article file or from the corresponding author upon reasonable request.

Code Availability Not aplicable.

\section{Declarations}

Conflict of interest Manuel Rivas Cañas declares that he has no conflict of interest. The authors certify that they have NO affiliations with or involvement in any organization or entity with any financial interest (such as honoraria; educational grants; participation in speakers' bureaus; membership, employment, consultancies, stock ownership, or other equity interest; and expert testimony or patentlicensing arrangements), or non-financial interest (such as personal or professional relationships, affiliations, knowledge or beliefs) in the subject matter or materials discussed in this manuscript.

Ethics Approval Not aplicable.

Consent to Participate Not aplicable.

Consent for Publication I, Manuel Rivas, give my consent for the publication of identifiable details, which can include photograph(s) and/or details within the text ("Material") to be published in the above Journal and Article. I confirm that I have seen and been given the opportunity to read both the Material and the Article (as attached) to be published by Springer.

Open Access This article is licensed under a Creative Commons Attribution 4.0 International License, which permits use, sharing, adaptation, distribution and reproduction in any medium or format, as long as you give appropriate credit to the original author(s) and the source, provide a link to the Creative Commons licence, and indicate if changes were made. The images or other third party material in this article are included in the article's Creative Commons licence, unless indicated otherwise in a credit line to the material. If material is not included in the article's Creative Commons licence and your intended use is not permitted by statutory regulation or exceeds the permitted use, you will need to obtain permission directly from the copyright holder. To view a copy of this licence, visit http://creativecommons. org/licenses/by/4.0/.

\section{References}

1. M. J. Berridge, M. D. Bootman, and H. L. Roderick (2003). Nat. Rev./Mol. Cell Biol. 4, 517. https://doi.org/10.1038/nrm1155.

2. T. Byers et al (2002). CA 52, 92. https://doi.org/10.3322/canjclin. 52.2.92.

3. M. L. McCullough, A. S. Robertson, C. Rodriguez, E. J. Jacobs, A. Chao, J. Carolyn, E. E. Calle, W. C. Willett, and M. J. Thun (2003). Cancer Causes Control 14 (1), 1. https://doi.org/10.1023/ a:1022591007673.

4. M. C. Curry, A. A. Peters, P. A. Kenny, S. J. Roberts Thomson, and G. R. Monteit Monteit (2013). Biochem. Biophys. Res. Commun. 434, 695. https://doi.org/10.1016/j.bbrc.2013.04.015.

5. V. Zaichick, S. Zaichick, and M. Rossmann (2016). AIMS Mol. Sci. 3 (4), 635. https://doi.org/10.3934/molsci.2016.4.635.

6. D. Clapham (2007). Cell 131, 1047. https://doi.org/10.1016/j.cell. 2007.11.028.

7. A. E. West (2001). Proc. Natl. Acad. Sci. USA 98, 11024. https:// doi.org/10.1073/pnas.191352298.

8. L. Contreras (2010). Biochim. Biophys. Acta 1797, 607. https:// doi.org/10.1016/j.bbabio.2010.05.005.

9. Z. Saidak (2009). Endocrinol. Rev. 30, 1787. https://doi.org/10. 1210/er.2008-0041. 
10. D. G. Nicholls, S. L. Budd, and R. F. Castilho (1999). Biochem. Soc. Symp. 66, 55. https://doi.org/10.1042/bss0660055.

11. P. S. Brookes, Y. Yoon, and S. S. Sheu (2004). Am. J. Physiol. Cell Physiol. 287, C817. https://doi.org/10.1152/ajpcell.00139. 2004.

12. P. Storz (2005). Front. Biosci. 10, 1881. https://doi.org/10.2741/ 1667.

13. H. Pelicano (2004). Drug Resist. Updates 7, 97. https://doi.org/ 10.1016/j.drup.2004.01.004.

14. H. Pelicano (2009). Cancer Res. 69, 2375. https://doi.org/10. 1158/0008-5472.CAN-08-3359.

15. N. Vanlangenakker and T. Vanden (2008). Curr. Mol. Med. 8(3). https://doi.org/10.2174/156652408784221306.

16. S. Y. Proskuryakov and V. L. Gabai (2010). Curr. Pharm. Des. 16 (1), 56. https://doi.org/10.2174/138161210789941793.

17. R. A. Willis, Pathology of tumours, 4th ed. (Butterworths, London, 1967).

18. J. Folkman and R. Kerbel (2002). Nat. Rev. Cancer 2, 717. https://doi.org/10.1038/nrc905.

19. J. Folkman (2003). Semin. Cancer Biol. 13, 159. https://doi.org/ 10.1016/s1044-579x(02)00133-5.

20. M. Rivas, L. J. del Valle, A. M. Rodriguez-Rivero, P. Turon, J. Puiggalí, and C. Alemán (2018). ACS Biomater. Sci. Eng. 26, 3234. https://doi.org/10.1021/acsbiomaterials.8b00353.

21. H. Klug and L. Alexander, X-Ray Diffraction Procedure for Polycrystallite and Amorphous Materials, 2nd ed. (John Wiley and Sons Press, New York, 1974).

22. E. Landi, A. Tampieri, G. Celotti, and S. Sprio (2000). J. Eur. Ceram. Soc. 20, 2377. https://doi.org/10.1016/S09552219(00)00154-0.

23. H. Orimo (2010). J. Nippon Med. Sch. 77, 4. https://doi.org/10. 1272/jnms.77.4.

24. W. Stockem, K. Weber, and J. Wehland (1978). Cytobiologie 70, 2463.

25. P. P. Roger, F. Rickaert, G. Huezt, M. Authelet, F. Hofmann, and J. E. Dumont (1988). FEBS Lett. 232 (2), 409.

26. X. H. Guan, Q. Liu, G. H. Chen, and C. Shang (2005). J. Colloid Interface Sci. 289, 319. https://doi.org/10.1016/j.jcis.2004.08. 041.
27. V. Dalmoro, J. H. Z. dos Santos, E. Armelin, C. Alemán, and D. Azambuja (2013). Appl. Surf. Sci. 273, 758. https://doi.org/10. 1016/j.apsusc.2013.02.131.

28. X. L. Zhu, J. Chen, L. Scheideler, R. Reichl, and J. Geis-Gerstoefer (2004). Biomaterials 25, 4087. https://doi.org/10.1016/j. biomaterials.2003.11.011.

29. W. Y. P. Y. Shih and T. S. Chin (1999). J. Non-Cryst. Solids 244, 211. https://doi.org/10.1016/S0955-2219(00)00113-0.

30. H. Goretzki, H. U. Chun, M. Sammet, and R. Bruckner (1980). J. Non-Cryst. Solids 42, 49. https://doi.org/10.1016/00223093(80)90007-1.

31. C. S. K. Singamsetty, C. U. Pittman, G. L. Booth, G. R. He, and S. D. Gardner (1995). Carbon 33, 587. https://doi.org/10.1016/ 0008-6223(94)00144-O.

32. S. Neumann (2009). Biomaterials 30, 6794. https://doi.org/10. 1016/j.biomaterials.2009.08.043.

33. J. T. Taylor, X. B. Zeng, J. E. Pottle, K. Lee, et al. (2008). World J. Gastroenterol. 14, 4984. https://doi.org/10.3748/wjg.14.4984.

34. R. A. Steinhardt and J. Alderton (1988). Nature 332, 364.

35. A. E. Ewence, M. Bootman, et al. (2008). Circ. Res. 103. https:// doi.org/10.1161/CIRCRESAHA.108.181305.

36. L. Kaestner, X. Wang, L. Herts, and I. Bernhard (2018). Front. Physiol. 9, 450. https://doi.org/10.3389/fphys.2018.00450.

37. S. Marchi and P. Pintoni (2016). Curr. Opin. Pharmacol. 29, 1. https://doi.org/10.1016/j.coph.2016.03.002.

38. V. Farfariello, O. Lamshanova, E. Germania, I. Fliniaux, and N. Prevarskaya (2015). Biochem. Biophys. Acta 1853 (9), 1974. https://doi.org/10.1016/j.bbamcr.2015.03.005.

39. M. Rivas, J. Casanovas, L. J. del Valle, O. Bertran, G. RevillaLópez, P. Turon, J. Puiggalí, and C. Alemán (2015). Dalton Trans. 44, 9980. https://doi.org/10.1039/C5DT00209E.

40. L. Bloch-Frankenthal (1954). Biochem. J. 57 (1), 87. https://doi. org/10.1042/bj0570087.

41. E. D. Eanes, P. H. Gillesen, and A. S. Posner (1965). Nature 208, 365 .

42. M. Kunitz (1952). J. Gen. Physiol. 35 (3), 423. https://doi.org/10. 1085/jgp.35.3.423.

Publisher's Note Springer Nature remains neutral with regard to jurisdictional claims in published maps and institutional affiliations. 